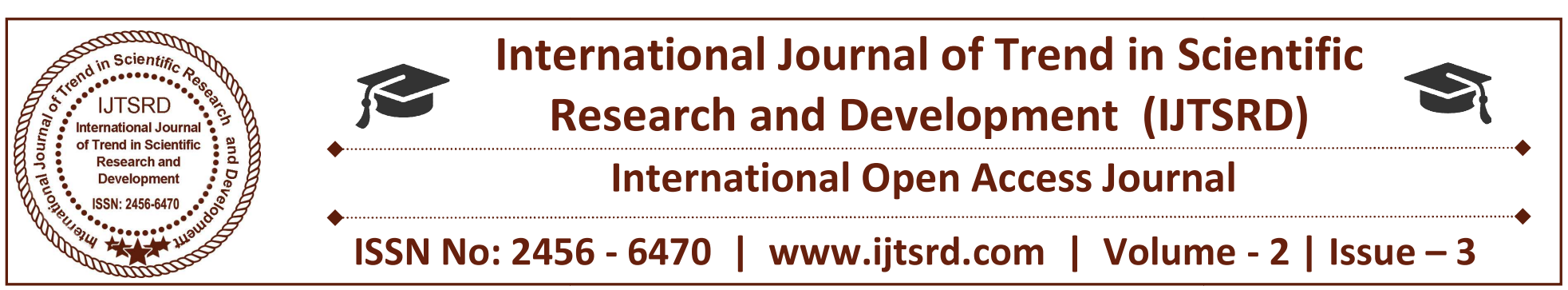

\title{
Combatting Sexual Harassment of Women at Workplace
}

\author{
Arpita Sahu \\ Presidency University, Bangalore, Karnataka, India
}

\begin{abstract}
More and more women are taking up salaried jobs but old attitudes remain the same. It is the institutional process that should guarantee a safe workplace for women, haven't caught up yet. Though the number of women in workforce has been rising but there is little or no change in the mindset of the community. The risk of women, being victims of sexual harassment is endless. It need to be controlled and appropriate action in such cases is absolutely essential. After all right to life means life with dignity. Gender equality includes protection from sexual harassment and right to work with dignity. So every step taken in this direction, is a definite move towards civilization and refinement of the Society.
\end{abstract}

Women constitute about one half of the global population, but at the work place they are placed at various disadvantageous positions due gender difference and bias. Keeping in view tradition-bound society, our Constitution has made number of safeguards for protecting the rights and status of women and one such provision in this direction is bring the Sexual Harassment of Women at Workplace( Prevention, Prohibition and Redressal) Act, 2013 into the statute book.

Keywords: Sexual Harassment, Constitution of India, Sexual Harassment of Women at Workplace, gender equality

\section{INTRODUCTION}

It is a universal concept that in general the men are physically stronger than women .But as far as the mental intelligence is concerned; women have proved and established that they are more brilliant than men. It is an important concept that men and women are complement to each other in all needs for the formation of a civil society or family.

It has been realized from the very inception of the family since the ancient past by the intellectuals that the upliftment of females play a very important role in upliftment the of civil society. So in this respect several measures have been introduced from time to time to protect the women from the misuse of physical power by the men against them after all a safe workplace is a woman's legal right. Indeed, the Constitutional doctrine of equality and personal liberty is contained in Articles 14, 15 and 21 of the Indian Constitution. These articles ensure a person's right to equal protection under the law, to live a life free from discrimination on any ground and to protection of life and personal liberty.

Article 11 of the Convention on "Elimination of All Forms of Discrimination (CEDAW), to which India is a party, requires State Government to take all appropriate measures to eliminate gender discrimination against women in the field of employment. Furthermore, in order to achieve this goal i.e., to eliminate discrimination against women, the Parliament of India enacted The Sexual Harassment of Women At Workplace (Prevention, Prohibition, and Redressal) Act, 2013.

The purpose of the present act is to achieve better cooperation from the females to meet the demands of modernization of standard of living, education and other social needs. Now-a-days, the percentage of number of service women is increasing day by day and they are working all the 24 hours of the day and even joining all kinds of job. Days have gone when the women had an inferiority complex to that extent that they were neither allowed to peep outside the house except with permission of the male members 
of the family. But with the increase of women's participation in every sphere of life, the need for providing protection from the male became necessary to increase the protective measures for this purpose.

It has been observed that women's overall work participation would be 86.2 per cent. While according to official data, it shows that women's work participation rate is around $25.3 \%$ in rural area and $14.7 \%$ in urban areas, and this estimation indicate that there is a huge workforce of women, therefore there is a need to secure their workplace and entitlements.

The concept of "sexual harassment" has been defined by the courts including Supreme Court in the case of Vishaka v. State of Rajasthan ${ }^{11}$. It has been observed that that sexual harassment I s a form of sex discrimination projected through unwelcome sexual advances, request for sexual favours and other verbal or physical conduct with sexual overtones, whether directly or by implication, particularly submission to or rejection of such a conduct by the female employee was capable of being used for effecting the employment of the female employee and unreasonably interfering with her work performance and had the effect of creating a hostile working environment for her.

After looking upon the case of Vishaka, the Supreme Court placed an obligation on workplaces, institutions and those in positions of responsibility, to uphold working women's fundamental right to equality and dignity at the workplace. Three key obligations were imposed on institutions to meet that standard, namely

1) Prohibition

2) Prevention

3) Redress

${ }^{1}$ AIR 1997 SC 3011

\section{DEFINITION OF WORKPLACE SEXUAL HARASSMENT}

This section particularly talks about aggrieved women, workplace and sexual harassment as well as highlights key elements of workplace sexual harassment.

\section{AGGRIEVED WOMEN}

Any women irrespective of age, whether employed or not who alleges to have been subjected to any act of sexual harassment through unwelcome sexual advances, request for sexual favours and other verbal or physical conduct with sexual overtones or even try to molest a women etc by any man, either at a workplace or dwelling -place or at anywhere else would be called as 'aggrieved women'.

\section{WORKPLACE}

A workplace can be defined as any place visited by the employee arising out of or during the course of employment including transportation provided by the employer for undertaking such journey.

\section{SEXUAL HARASSMENT}

The term 'sexual harassment' has been defined under section 2(n) of the Act. This term includes one or more unwelcome acts or behavior( whether directly or by implication)namely:

i. Physical contact

ii. A demand for sexual favour

iii. Making sexually coloured remarks

iv. Any other unwelcome physical, verbal or non-verbal conduct of sexual nature

\section{TYPES OF SEXUAL HARASSMENT}

There are two forms of Sexual Harassment :

1) QUID PRO QUO:- It means this for that. It involve expressed or implied demand for sexual favour in exchange for same benefit(e.g., a promotion, pay increase) or to avoid detriment in the workplace

2) Hostile Work Environment:- Creation of a hostile work environment will affect her health and also her safety. 
The three key obligations imposed on the workplaces to uphold working women's fundamental right to equality and dignity at the workplace are:

\section{PROHIBITION AND PREVENTION}

This part talks about those who are responsible for the prohibition and prevention of sexual harassment and role of workplaces in prohibiting sexual harassment through effective policies at workplace.

There are three effective preventive authorities:

\section{1) APPROPRIATE}

GOVERNMENT:-

Appropriate Government have to monitor implementation and maintain data on the number of cases filed and disposed of in respect of all cases related to sexual harassment of women at workplace.

2) EMPLOYER:- Employer is the head of the organization who is responsible for the management, supervision and control of designated workplace.

3) DISTRICT OFFICER:- This person is responsible for creating awareness about sexual harassment and rights of women.

\section{REDRESS}

This part talk about redressal i.e., who can complain and where and what the complain should contain.

\section{COMPLAINING PARTIES}

If the aggrieved women is unable to make complaint because of physical incapacity or death, a complaint can be filed by her relative or friend, her co-worker, or any person who has knowledge of the incident, either with her written consent or consent of her legal heir to Local Complaints Committee.+

\section{CONTENTS OF THE COMPLAINT}

The written complaint should contain a description of each incident(s). It should include relevant dates, timings and locations; name of the respondent(s); and the working relationship between the parties. A person designated to manage the workplace sexual harassment complaint is required to provide assistance in writing of the complaint if the complainant seeks it for any reason.

\section{EMPLOYEES} COMPLAINT

EXPECTATION

$\mathbf{O N}$

The employee expects enabling support and assistance if the complaint lead to criminal proceeding and they also have the right to expect a trained and skilled Complaints Committee to keep their information confidential and in return also expect justice for the wrong caused to them.

\section{MEASURES TO COMBAT SEXUAL HARASSMENT OF WOMEN AT WORKPLACE}

It should kept in mind that this is a workplace where harassment will not be tolerated.

Development of anti-harassment policies with employees, managers, and union representatives

There should be ensurement that all the managers and supervisors understand the responsibility to provide a harassment free work environment.

The policies should be communicated properly to the employees.

Protective environment and proper support system should be created for the employees who feel harassed

The Policies related to sexual harassment should be monitored and revised on regular basis to ensure its effectiveness in the workplace.

Enforcement of policies to each and everyone i.e., including managers and supervisors.

Men and women should be included in building a culture which no longer tolerates workplace sexual harassment.

All employees should understand the policy and procedures for dealing with harassment and that involves training, information and education.

Undertake orientation on workplace sexual harassment for all workers in respective organizations, establishments or institutions. 


\section{CONCLUSION}

Sexual Harassment of Women at Workplace constitutes a gross violation of women's right to equality and dignity. This creates a negative impact on their lives and livelihood and leads to poor productivity. So a sense of security at the workplace will lead to women's participation in work, resulting in their economic empowerment and inclusive growth. It will also contribute to the realization of their right to gender equality, life and liberty, equality in working conditions everywhere.

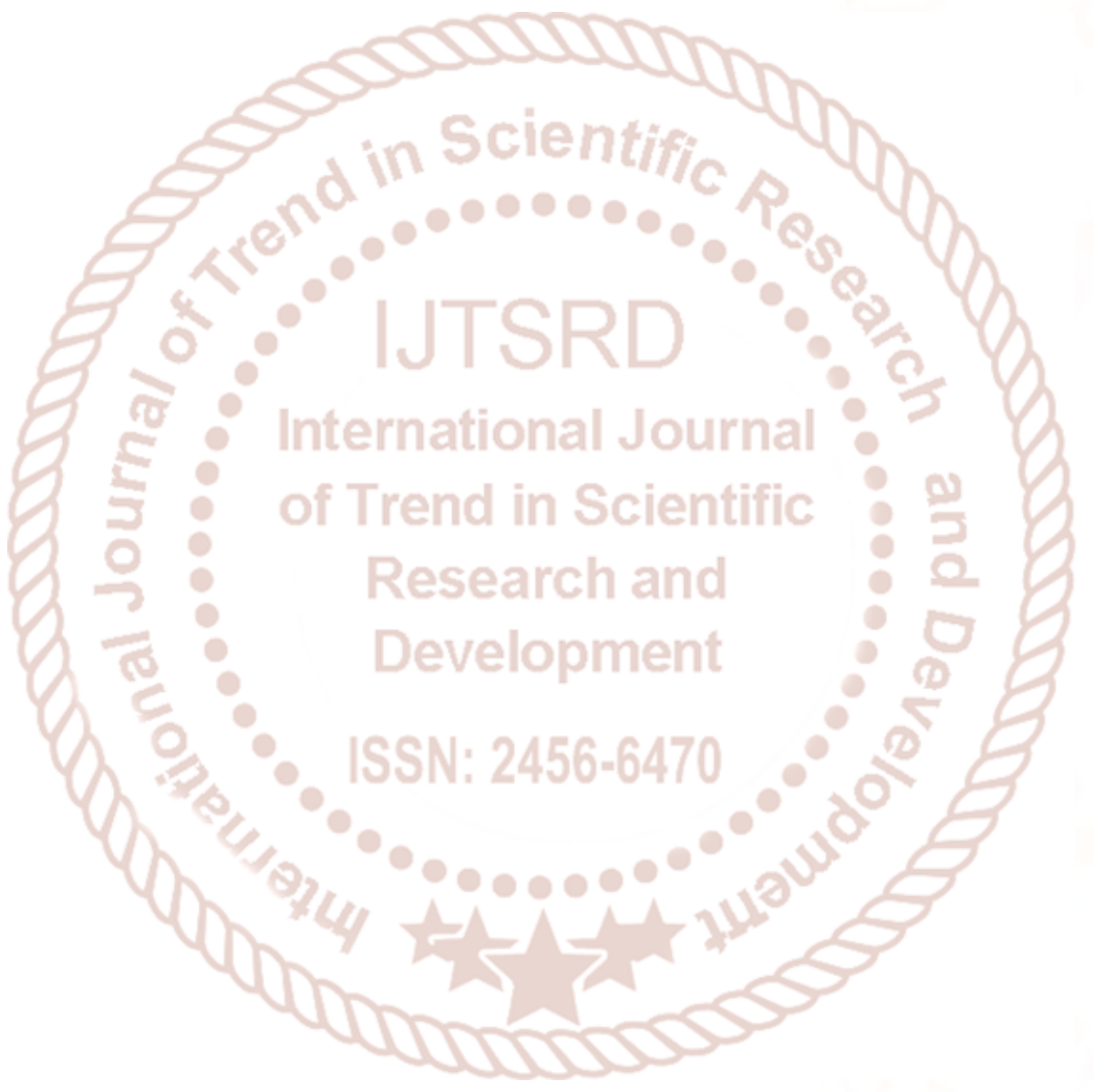

